\title{
Economic Performance: Leading Sector, Economic Structure and Competitiveness of Export Commodities
}

\author{
Adi WIJAYA ${ }^{1}$, Zainal ILMI ${ }^{2}$, Dio Caisar DARMA ${ }^{3}$
}

Received: January 15, 2020. Revised: January 23, 2020. Accepted: July 05, 2020

\begin{abstract}
Purpose: The purpose of this study is for the leading sector, a pattern of shifting structure of the economic sector, and community export competitiveness on the economy Malinau Regency. Research design, data, and methodology: The type of data used is secondary data with a quantitative approach of 2009-2018. The study data used Location Quotient (LQ), Shift Share Analysis (SSA), and Revealed Comparative Advantage (RCA) analysis tools. Results: There are 6 leading sectors: agriculture; electricity, gas, and clean water; building and construction; trade, hotels, and restaurants. That has been classified has changed the economic structure of the Malinau Regency from the secondary sector to the tertiary and primary sectors in 10 years. While, community export competitiveness of the Malinau Regency through RCA Analysis, see if the export products of coal and excavation (types A, B, C) are shown to have a higher comparative advantage with comparative advantage. This shows that only a few commodities that can provide the good performance of export. Conclusions: Analysis of economic growth in the Malinau Regency after regional autonomy shows that there has been a shift in the economic structure of the economy which is dominated by the structure of the primary sector.
\end{abstract}

Keywords : Leading Sector, Economic Structure, Export Commodity, Competitiveness

JEL Classifications: A11, N1, H87, F12

\section{Introduction}

Clearly, the economic analysis of regional growth and its distribution already has a long history and dates back to classical economists such as Marshall (1920). From an analytical perspective, the foundations of modern economic growth theory can be found in the early work in which he

1 Head Lector, Department of Economics, Faculty of Economics and Business, Mulawarman University, Indonesia. Email: adi.wijaya@feb.unmul.ac.id

2 Senior Lecturer, Department of Management, Faculty of Economics and Business, Mulawarman University, Indonesia, Email: zainal.ilmi@feb.unmul.ac.id

3 Corresponding Author, Lecturer, Department of Management, Sekolah Tinggi llmu Ekonomi Samarinda, Indonesia.

Email: diocaisar@stiesam.ac.id

(c) Copyright: The Author(s)

This is an Open Access article distributed under the terms of the Creative Commons Attribution Non-Commercial License (https://creativecommons.org/licenses/by-nc/4.0/) which permits unrestricted non-commercial use, distribution, and reproduction in any medium, provided the original work is properly cited. argues that, in a neoclassical economic world, the growth rate of a region (measured in per capita income) is inversely related to its initial per capita income, a thesis which offers an optimistic perspective for poor regions. Interesting regional growth models have been extensively developed in the $1960 \mathrm{~s}$, in particular, in a neoclassical framework (Borts, 1960; Borts \& Stein, 1964, 1968; Solow, 1965).

The spatial-economic convergence idea has attracted considerable attention over the years and has generated interesting applied research on evolving convergence versus persistent disparities (Barro \& Sala-i-Martin, 1992; Wahyuningsih, Yunaningsih, Priadana, Wijaya, Darma, \& Amalia, 2020a).

Exports provide an interface into how globally competitive a country is. Likewise, a robust export base secures a country against deteriorating current account balance. In general, exports facilitate the exploitation of economies of scale, allow resource allocation according to comparative advantage, improve foreign exchange reserves 
position guaranteeing easy financing of imports, increase efficiency and productivity through competition, increase employment, and allow for knowledge spill-overs that will encourage domestic innovation. There is strong evidence in the literature favoring exports as an important driver of sustainable economic growth. It has also been proven in the case of South Asian economies in general and Pakistan in particular (Kemal, Din, Qadir, Fernando, \& Colombage, 2002; Weiss, 2005).

Exports have long been the strength of the Indonesian economy. Indonesia in the Soeharto Era, known as the world's major oil producer and exporter. Indonesia entered the ranks of the 11 largest oil producers in the world. However, massive oil production throughout the New Order period caused oil reserves to decline sharply. Since the 1980s, Indonesia has no longer dependent on oil and gas exports, the non-oil and gas sector has dominated Indonesia's exports. This is evident from the role of non-oil (gas exports) in 2015 reaching $87.65 \%$. Several Indonesian non-oil commodities can triumph in international markets is plantation commodities such as palm oil, rubber, coffee, and cocoa. In addition, Indonesia's mining commodities can also control world market shares such as coal and natural gas (Darma, Haryadi, \& Umiyati, 2015; Wahyuningsih, Yunaningsih, Priadana, Darma, \& Purwadi, 2020b).

Another problem of Indonesian exports is export destination countries which are still concentrated in certain countries such as the United States, China, and Japan. As a result of dependence on the countries that mentioned is very large. Any turmoil that occurs in the country will affect export performance. This turmoil is not limited only to economic turmoil but also the non-economic that occurs in the country (Wijayanti \& Darma, 2019).

Malinau Regency is an area of division from Bulungan Regency based on Law of the Republic of Indonesia Number: 22 of 1999 and Law of the Republic of Indonesia Number: 47 of 1999. Malinau Regency is also part of the North Kalimantan Province, which is also the result of the division of East Kalimantan Province in 2012. Since it has only been formed in recent years, Malinau Regency still has shortcomings in terms of government, human resources, infrastructure, facilities, and infrastructure. Until now, Malinau Regency is in a stage of regional development process.

The rate of economic growth in Malinau Regency over several periods (2014-2018) has experienced a downward trend of $6.53 \%$. The highest economic growth occurred in 2016, reaching $11.55 \%$, and the lowest in 2018 of $3.67 \%$. However, in general, the Malinau Regency falls into the very high category of regional economic growth (Tarigan, 2005).

Based on records from the BPS-Statistics of Malinau Regency (2019), the pattern of economic growth in the
Malinau Regency in the 2014-2018 period was mainly supported by the primary structure consisting of: the agricultural sector, and the mining and quarrying sector to an average of $53.38 \%$. Thus, these two sectors are considered to be the leading sectors in Malinau Regency. Considering the potential of economic resources in the contribution of Gross Regional Domestic Product (GRDP), the largest primary structure, among others, comes from the vast land area of the Malinau Regency forest (see Figure 1).

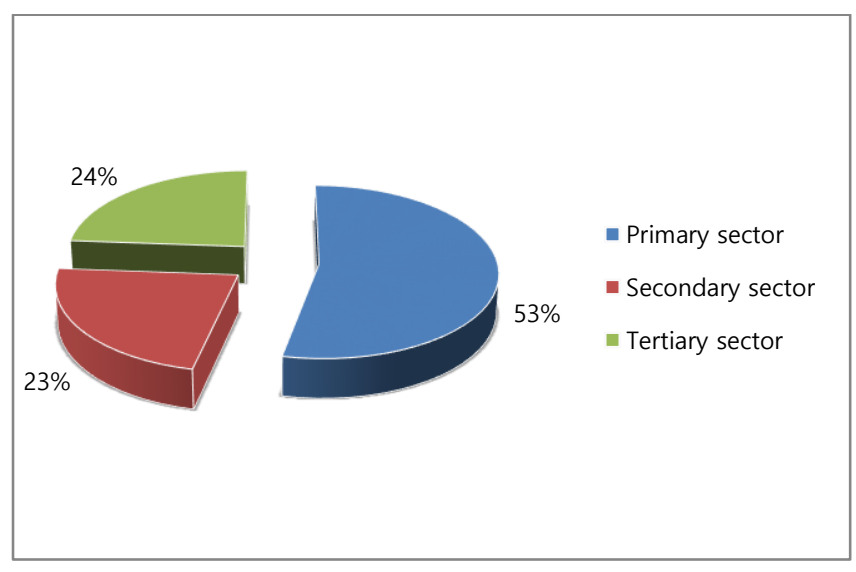

Figure 1: Average Economic Structure in Malinau Regency, 2014-2018 (\%)

The structure of the second largest economic sector comes from the tertiary structure which includes the trade, hotel and restaurant sector, the transportation and communication sector, the financial sector, and leasing and business services, and the service sector with an average contribution of $23.84 \%$. Meanwhile, the third position is the structure of the secondary economic sector consisting of: the industrial sector of processing, the electricity sector, gas and clean water, and the construction sector with an average contribution of $22.78 \%$.

The next problem is that the existing economic growth is not yet known as economic sectors that have the potential for competitive and comparative competitiveness so that the existing growth is only limited to quantitative figures. For this reason, after the leading sector is known, it is continued, with the identification of sectors that have the potential for competitive and comparative competitiveness.

The objectives to be obtained from this study are to identify:

- Leading sectors in the economy of the Malinau Regency region.

The pattern of shifting structure of the economic sector in the economy of the Malinau Regency.

- Competitiveness of export commodities in the economy of the Malinau Regency. 


\section{Literature Review}

\subsection{Leading Sector Theory}

This Leading Sector Theory is based on the export of goods (commodities). The goals of developing this theory are to increase the rate of growth, job creation, and increase in income. The process of regional development is responding to foreign or domestic demand, beyond modality, and multiplier effects. For this reason, there is integration between types of industries, infrastructure, and industrial expansion. Hypotheses can be arranged, in addition to location also the sectoral role and Location Quotient (LQ) housing construction sector (real estate) in one area (Miller \& Geltner, 2004).

\subsection{Patterns of Development Theory}

The pattern of development theory focuses on structural shifts in the stages of the process of economic, industrial and institutional change in a gradual manner in a backward economy, thus enabling the emergence of new industries to replace the position of the agricultural sector as a driver of economic growth.

The results of empirical research conducted that in line with the increase in income per capita that brought a change in consumer demand patterns from an emphasis on food and other necessities to a variety of manufactured goods and service, the accumulation of physical and human capital, the development of cities, and industries in urban areas together with the migration process of population from rural to urban areas. A decrease in population growth rates and smaller family sizes, the economic structure of a country shifts from what was originally dominated by the agriculture or mining sector to non-primary sectors, especially industry (Chenery \& Syrquin, 1975; Darma, Kasuma, \& Ikbal, 2020; Chulanova, 2017).

\subsection{Export Base Theory}

This theory divides the production sector or type of work contained in an area on the basis of work (basic) and service work (non-basis). Base activities are exogenous activities, which means they are not tied to the internal economic conditions of the region and at the same time function to encourage the growth of other types of work. Meanwhile, non-base activities are activities to meet the needs of the community in the area itself (Douglas, 1995; Tiebout, 1956).

Some points of emphasis in the export base theory model, among others, are the following:
- That an area does not have to be an industrial area to be able to grow quickly, because the determining factor for regional growth is the comparative advantage (location advantage) that the region has.

- The economic growth of a region will be maximized if the region concerned utilizes the comparative advantage it possesses into the strength of its export base.

- Inequality between regions remains very large influenced by variations in the potential of each region.

\section{Research Methods and Materials}

\subsection{Research Design}

The research framework is essentially a description of how a researcher is to meet the objectives of the study. In other words, a research design is a logical plan to test hypotheses, so that by looking at the research design can be known direction, research objectives, to the type and type of research (Nur, 2010; Darma, 2019).

\subsection{Data Type and Source}

This type of research is quantitative descriptive research conducted to describe a variable independently, either one or more variables without making comparisons or connecting variables with other variables (Marzuki, 1999).

In conducting studies, the data needed is secondary data. This secondary data can be in the form of journals, papers or research results that have been done before (Kuncoro, 2003). This data is also in the form of reports or publications from Government Agencies, i.e: Central Statistics Agency, Regional Planning and Development Agency, Malinau Regency and North Kalimantan Province.

Because the data needed in this study is secondary data, the collection technique is in the form of library research. Data collected through reading and recording data, reports, and theories that have a relationship with the problem that will be discussed in the research (Aswandi \& Kuncoro, 2002).

\subsection{Analysis Model}

The Location Quotient (LQ) method is used to determine whether economic sectors or sub-sectors are considered superior or non-featured activities (Tarigan, 2007). The formula of LQ is:

$$
L Q: \frac{x_{i n} / y n}{x_{i} / y}
$$


Where, LQ is comparison between sector or sub-sector market share (i) in Malinau Regency and sector (i) in North Kalimantan Province; Xin is GRDP value of the sector or sub-sector (i) in Malinau Regency; Xi is value of sectoral or sub-sector GRDP (i) in North Kalimantan Province; Yn is total GRDP value in Malinau Regency; and Y is total GRDP value in North Kalimantan Province.

The range of $L Q$ values is $L Q>1$, meaning, the sector or sub-sector (i) is categorized as a leading sector that is able to export its products to other regions. $\mathrm{LQ}<1$, means the sector or sub-sector (i) is categorized as a non-leading sector, which tends to import products from other regions.

In the Shift Share Analysis (SSA), dividing regional growth into 3 components, i.e: national growth $(\mathrm{N})$, mixed industry (industrial mix) (M), and competitive advantage (C). The effect of national growth is called the share effect, and the influence of the industrial mix is called the proportional shift or composition mix. Finally, the effect of competitive advantage is called differential shift or regional share.

If this analysis model is applied and operationalized to regional income (GRDP), then:

$$
N_{i j}=Y_{i j} . R_{n}
$$

Where, $\mathrm{N}_{\mathrm{ij}}$ is a growth of GRDP sector (i) Malinau Regency is influenced by GRDP growth in North Kalimantan Province; $Y_{i j}$ is GRDP in the sector $i$ of Malinau Regency; $r_{n}$ is Total GRDP growth in North Kalimantan Province.

This equation is for calculating and analyzing the relationship of the North Kalimantan Province GRDP growth component to the Malinau Regency GRDP growth in North Kalimantan Province.

$$
M_{i j}=Y_{i j .}\left(r_{i n}-r_{n}\right)
$$

Where, $\mathrm{M}_{\mathrm{ij}}$ is GRDP growth in sector (i) of Malinau Regency, which is influenced by the industrial mix of North Kalimantan Province; $\mathrm{Y}_{\mathrm{ij}}$ is PDRB sector (i) of Malinau Regency in North Kalimantan Province; $r_{i n}$ is GRDP growth in (i) Province North Kalimantan; $r_{n}$ is North Kalimantan's total GRDP growth.

$\mathrm{C}_{\mathrm{ij}}$ equation to calculate and analyze the interrelations of each sector in the Shift-Share Analysis, to measure how far the Regency sector in North Kalimantan Province has component advantages due to the regional mix industry The values of $r_{i j}, r_{i n}$, and $r_{n}$ are each defined as:

$$
\begin{aligned}
& r_{i j}=\left(Y_{i j}-Y_{i j, t-1}\right) / Y_{i j, t-1} \\
& r_{i n}=\left(Y_{i n}-Y_{i n, t-1}\right) / Y_{i n, t-1}
\end{aligned}
$$

$$
r_{n}=\left(Y_{n}-Y_{n}, t-1\right) / Y_{n}, t-1
$$

Where, $Y_{\text {in }}$ is GRDP sector (i) in North Kalimantan Province. $Y_{\text {in }}, t-1$ is GRDP sector (i) in North Kalimantan Province the previous year; $\mathrm{Y}$ is total GRDP of North Kalimantan Province; $\mathrm{Y}_{\mathrm{n}}$, $\mathrm{t}-1$ is total North Kalimantan GRDP of the previous year; $Y_{i j}$ is GRDP sector (i) in Malinau Regency; $\mathrm{Y}_{\mathrm{ij}}$, $\mathrm{t}-1$ is GRDP sector (i) in Malinau Regency the previous year.

For a region, national growth $\left(\mathrm{N}_{\mathrm{ij}}\right)$, industry $\operatorname{mix}\left(\mathrm{M}_{\mathrm{ij}}\right)$, and competitive advantage $\left(\mathrm{C}_{\mathrm{ij}}\right)$ can be determined for a sector i or summed up for all sectors as a whole region. Shift share equation for sector (i) in region (j) is:

$$
D Y_{i j}=Y_{i j} . r_{n}+y_{i j}\left(r_{i n}-r_{n}\right)+y_{i j}\left(r_{i j}-r_{i n}\right)
$$

The $D Y_{i j}$ equation or the Shift-Share (S-S) equation imposes each sector in the Malinau Regency with a growth rate equivalent to the rate achieved by the national economy during the analysis period. This is reflected in equation $\left(\mathrm{C}_{\mathrm{ij}}\right)$, which shows that the Malinau Regency region and sectors should at least grow at the national growth rate, namely $r_{n}$.

In measuring the comparative advantage level or day power of an export commodity from Malinau Regency as compared to the same quantity at the North Kalimantan Province level, the Revealed Comparative Advantage (RCA) index formula is used as follows:

$$
R C A=\frac{X_{i k} / X_{i m}}{X_{w k} / X_{w m}}
$$

Where, $X_{\text {ik }}$ is value of commodity exports (i) from Regency Malinau; $X_{\text {im }}$ is the export value of all commodities from Malinau Regency; $\mathrm{X}_{\mathrm{wk}}$ is value of commodity exports (i) from all areas North Kalimantan; and $X_{w m}$ is the export value of all commodities from North Kalimantan Province.

The statement indicates if RCA $<1$, means that export commodities in Malinau Regency do not have a competitive edge. $\mathrm{RCA}=1$, indicates that export commodities in Malinau Regency have the same comparative advantage as the Province of North Kalimantan. RCA> 1, means that the export commodities in Malinau Regency have a comparative advantage that is higher than the comparative advantage of the same commodity exports at the level of North Kalimantan Province.

\section{Results and Discussion}

The complete LQ calculation results for each sector in Malinau can be seen in Table 1 . 
Table 1: Average LQ Results by Economic Sector in Malinau Regency, 2009-2018

\begin{tabular}{|c|c|}
\hline Business field & LQ \\
\hline Agriculture & 5.194 \\
\hline Mining and Quarrying & 0.425 \\
\hline Processing Industry & 0.003 \\
\hline Electricity, Gas and Clean Water & 1.338 \\
\hline Building and Construction & 3.419 \\
\hline Trade, Hotels and Restaurants & 1.250 \\
\hline Transportation and Communication & 0.520 \\
\hline Finance, Leasing and Corporate Services & 0.162 \\
\hline Services & 2.239 \\
\hline
\end{tabular}

Note: own calculation, 2019

The results of data processing show that of the 9 sectors in Malinau Regency, sectors that on average consistently had an LQ coefficient> 1 during the period 2009-2018 as follows: agriculture, electricity, gas and clean water, building and construction, trade, hotels and restaurants, and services. The agricultural sector is a business field that has the highest average LQ coefficient of 5.194 in Malinau Regency.

Meanwhile, the other 4 sectors that consistently had an average LQ coefficient $<1$ consisted of mining and quarrying, manufacturing industry, transportation and communication, finance, leasing and corporate services.

Gross Regional Domestic Product (GRDP) in this study is the output or value-added of the entire production of goods and services produced from several economic sectors (including its sub-sectors) are based on constant price prices in Malinau Regency in 2009-2018 in the unit of Million Rupiah (IDR).

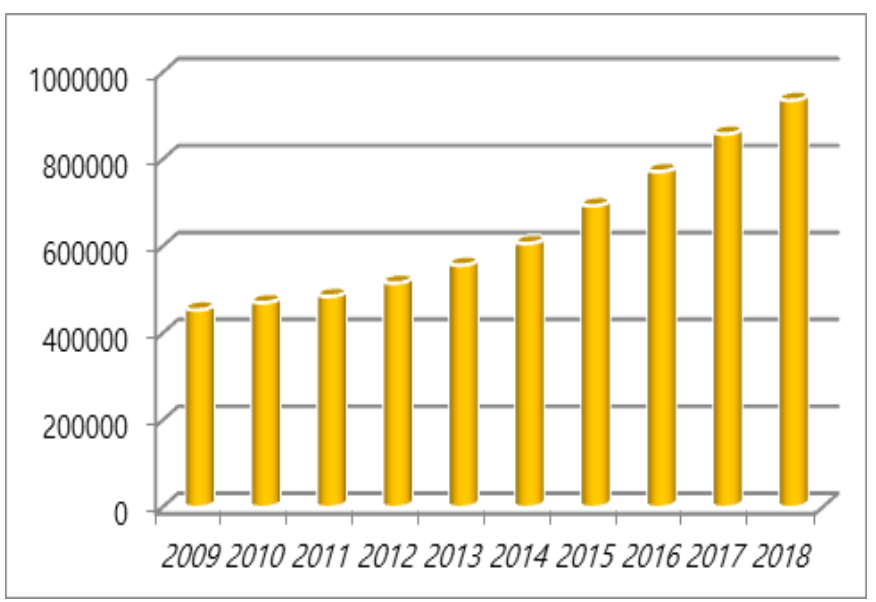

Figure 2: GRDP at Constant Prices in Malinau Regency, 2009-2018 (Million IDR)
Figure 2 shows significant increase in the development of GRDP in Malinau Regency during the observation period. The data shows that the highest PDRB value occurred in 2018, reaching 936,311 Million IDR, while in 2009 , it was 454,183 Million IDR.

SSA assumes that changes in the structure or economic performance of a region are influenced by the economic structure of a higher or wider regional unit (Arsyad, 2010).

Table 2: Average Shift Share Results Based on the National Growth Component $\left(\mathrm{N}_{\mathrm{ij}}\right)$ in Malinau Regency, 2009-2018

\begin{tabular}{|c|c|}
\hline Business field & $\mathbf{N}_{\mathrm{ij}}$ (Million IDR) \\
\hline Agriculture & $1,119,675$ \\
\hline Mining and Quarrying & $1,912,007$ \\
\hline Processing Industry & 3,656 \\
\hline Electricity, Gas and Clean Water & 19,297 \\
\hline Building and Construction & 671,317 \\
\hline Trade, Hotels and Restaurants & 725,722 \\
\hline Transportation and Communication & 117,143 \\
\hline Finance, Leasing and Corporate & 20,946 \\
\hline Services & 721.910 \\
\hline Services & 590,186 \\
\hline Average &
\end{tabular}

Note: own calculation, 2019

Changes in the relative structure or performance of the economy of the Malinau Regency to a wider region (North Kalimantan Province is influenced by several components, namely regional economic growth (Nij), industrial mix (Mij) and Competitive Advantage (Cij).

Malinau Regency's GRDP can be compared annually to the North Kalimantan Province's GRDP to see the performance of various sectors of the economy by referring to the base year of analysis and the final year of analysis. The decomposition of the business sector (shifting economic structure) of Malinau Regency is set out in Table 2 .

The highest growth was in the agriculture sector, and mining and quarrying in Malinau Regency was influenced by the growth of the same sector in North Kalimantan Province during 2009-2018, amounting to 1,119,675 and $1,912,007$ million rupiahs (IDR) for each sector.

The effect of Indonesia's economic growth shows the influence on the economy of the Malinau Regency with a positive value $\left(\mathrm{N}_{\mathrm{ij}}\right)$ in each economic sector so that the total value of output is 590,186 billion rupiahs (IDR). In addition, the increase in GDP growth value of the economic sector in Malinau Regency was influenced by several factors, including the influence of GDP growth in the economic sector of North Kalimantan Province $\left(\mathrm{N}_{\mathrm{ij}}\right)$ for 10 years with 
a total average of 590,186 million rupiahs (IDR) per year or $5.65 \%$ which caused by changes due to the effect of national growth, in this case, North Kalimantan Province. This shows that the economy of the Malinau Regency is still very dependent on the economy of North Kalimantan Province, Indonesia, and the global level.

Table 3: Average Shift Share Results Based on the Industrial Mix Component $\left(\mathrm{M}_{\mathrm{ij}}\right)$ in Malinau Regency, 20092018

\begin{tabular}{|c|c|}
\hline Business field & M $_{\mathrm{ij}}$ (Million IDR) \\
\hline Agriculture & $4,085,974$ \\
\hline Mining and Quarrying & $7,667,719$ \\
\hline Processing Industry & 1,891 \\
\hline Electricity, Gas and Clean Water & 51,612 \\
\hline Building and Construction & $6,877,577$ \\
\hline Trade, Hotels and Restaurants & $1,602,888$ \\
\hline Transportation and Communication & 359,516 \\
\hline Finance, Leasing and Corporate Services & 65,564 \\
\hline Services & $1,772,221$ \\
\hline Average & $2,498,329$ \\
\hline
\end{tabular}

Note: own calculation, 2019

The influence of the North Kalimantan Province $\left(\mathrm{M}_{\mathrm{ij}}\right)$ industrial mix is obtained from the sector GRDP (i) of the Malinau Regency region multiplied by the sector GRDP (i) growth or rin minus the North Kalimantan Province's total GRDP $\left(r_{n}\right)$ growth. The influence of the effect of the sectoral mix on the economic growth of Malinau Regency, with a total average of $23.93 \%$ or $2.498,329$ million rupiahs (IDR) for 10 years. This means that the influence of the industrial or sectoral mix effect is quite capable of driving the economic growth of the Malinau Regency. So, it can be said that the various sectors developed in Malinau Regency are in accordance with the sector developed at the Provincial level, in this case, North Kalimantan.

The positive influence of the industrial mix $\left(\mathrm{M}_{\mathrm{ij}}\right)$ component shows that the growth rate of the economic sector in Malinau Regency has increased. All sectors have experienced positive growth, where mining and quarrying were the sectors that had the highest average growth of 7,667,719 million rupiahs (IDR).

The influence of Malinau Regency's competitiveness on the economy of North Kalimantan Province was very large or positive, which was $70.41 \%$ or the average amount over the period 2009-2018 reaching 7,349,596 Million IDR. This is much higher than the influence of the economic growth component of North Kalimantan Province, thus indicating the high level of competitiveness or low independence of the Malinau Regency (Table 3).
Table 4: Results of Average Shift Share Based on the Competitive Advantage Component $\left(\mathrm{C}_{\mathrm{ij}}\right)$ in Malinau Regency, 2009-2018

\begin{tabular}{|c|c|}
\hline Business field & $\mathbf{C}_{\mathbf{i j}}$ (Million IDR) \\
\hline Agriculture & $-2,847,517$ \\
\hline Mining and Quarrying & $43,610,348$ \\
\hline Processing Industry & 19,160 \\
\hline Electricity, Gas and Clean Water & 211,872 \\
\hline Building and Construction & $-3,481,391$ \\
\hline Trade, Hotels and Restaurants & $1,836,460$ \\
\hline Transportation and Communication & 474,080 \\
\hline Finance, Leasing and Corporate Services & 143,869 \\
\hline Services & $26,179,482$ \\
\hline Average & $7,349,596$ \\
\hline
\end{tabular}

Note: own calculation, 2019

The mining and quarrying sector is a business field with the highest level of competitive advantage as compared to other commodities, reaching 43,610,348 million rupiahs (IDR), and the second is services totaling 26,179,482 million rupiahs (IDR). Table 4 has shown that there are 2 out of 9 sectors such as agriculture and building and construction are the economic sectors of the Malinau Regency which are not competitive (negative $\mathrm{C}_{\mathrm{ij}}$ ) compared to the same sector at the economy level of North Kalimantan Province.

This means that all sectors (except for the two sectors above), already have industries that are regionally developing in North Kalimantan Province, and the industrial structure is suitable for being in Malinau Regency. In 2018, the contribution of the effect of competitive advantage has increased as compared to the beginning of the study in 2009 , where there are already several sectors in Malinau Regency that have competitiveness.

Table 5: SSA Average Results by Economic Sector in Malinau Regency, 2009-2018 (Million IDR)

\begin{tabular}{|c|c|}
\hline Business field & $\mathbf{D}_{\mathbf{i j}}\left(\mathbf{N}_{\mathbf{i j}}+\mathbf{M}_{\mathbf{i j}}+\mathbf{C}_{\mathbf{i j}}\right)$ \\
\hline Agriculture & $2,358,132$ \\
\hline Mining and Quarrying & $53,190,074$ \\
\hline Processing Industry & 24,707 \\
\hline Electricity, Gas and Clean Water & 282,780 \\
\hline Building and Construction & $4,067,504$ \\
\hline Trade, Hotels and Restaurants & $4,165,070$ \\
\hline Transportation and Communication & 950,739 \\
\hline Finance, Leasing and Corporate Services & 230,380 \\
\hline Services & $28,673,614$ \\
\hline Average & $10,438,111$ \\
\hline
\end{tabular}

Note: own calculation, 2019 
Generally, empirical findings also apply to the amount of GRDP based on current prices per economic sector in Malinau Regency during 2009-2018 with an average amount of 10,438,111 million rupiahs (IDR) per year influenced by the cumulative GRDP growth of North Kalimantan Province by $3.53 \%$ per year. Thus, the value of GRDP growth in sector (i) of Malinau Regency was influenced by the growth of GRDP of North Kalimantan Province $\left(\mathrm{N}_{\mathrm{ij}}\right)$ reaching a total of 590,186 million rupiahs (IDR) per year, industry mix $\left(\mathrm{M}_{\mathrm{ij}}\right)$ of 2,498,329 million rupiahs (IDR) per year and competitive advantage $\left(\mathrm{C}_{\mathrm{ij}}\right)$ of $7,349,596$ million rupiahs (IDR) per year.

By the SSA, it is known that in the past decade the GRDP of Malinau Regency experienced an absolute value increase or an increase in regional economic performance with an average of 2,816,772 million rupiahs (IDR) per year. This can be seen from the positive PDRB component or diiferential shift $\left(\mathrm{D}_{\mathrm{ij}}\right)$ in all 9 business sectors in Malinau Regency, which reached an average of 10,438,111 million rupiahs (IDR) per year (see Table 5).

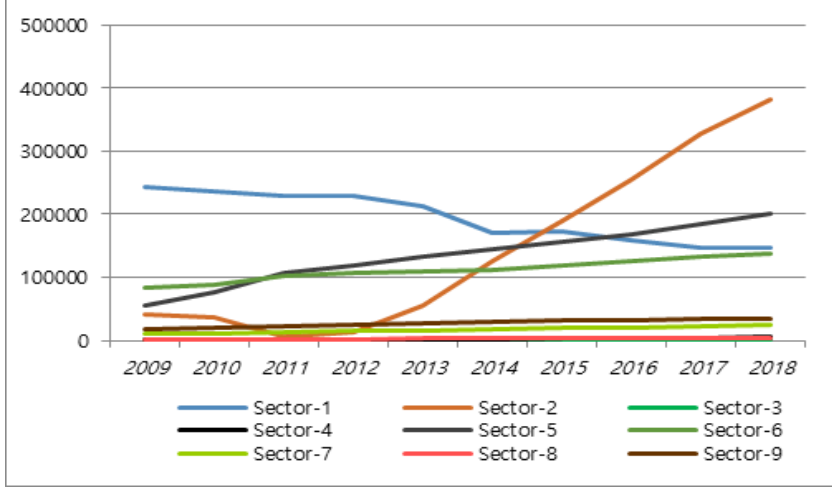

Figure 3: GRDP Based on Constant Prices by Busines Field in Malinau Regency, 2009-2018 (Million IDR)

In line with this fact, it is evident that when elaborated in the data that occurred from Figure 3 regarding the economic structure in Malinau during 2009-2018 experienced fluctuations. As for the nine sectors, which dominate according to rank, are as follows: Sector-1 (agriculture) with an average of 194,653 million rupiahs (IDR); followed by Sector-2 (mining and quarrying) with an average of 143,681 million rupiahs (IDR); Sector-5 (buildings and construction) with an average of 134,409 million rupiahs (IDR); Sector-6 (trade, hotels, and restaurants) with an average of 112,174 million rupiahs (IDR); from Sector-9 (services) with an average of 27,296 million rupiahs (IDR); Sector-7 (transportation and communication) with an average of 17,057 million rupiahs (IDR); Sector-4 (electricity, gas and clean water) with an average 2,753 million rupiahs (IDR); Sector-8 (finance, leasing and service companies) with an average of 2,573 million rupiahs (IDR) and then of Sector-3 (processing industry) with an average of 551 million rupiahs (IDR). Although the contribution of the agriculture sector is highest and dominates among others, from year to year this sector has seen a quite drastic decline.

Table 6: Level of Competitiveness of Exports of Agricultural Sector Commodity Products in Malinau Regency, 2009-2018

\begin{tabular}{|c|c|c|c|}
\hline \multirow{2}{*}{ Year } & \multicolumn{3}{|c|}{ Commodity } \\
\cline { 2 - 4 } & Palm oil & Rubber & Wooden logs \\
\hline 2009 & 0.002 & 0.001 & 0.766 \\
\hline 2010 & 0.001 & 0.001 & 0.585 \\
\hline 2011 & 0.001 & 0.001 & 0.796 \\
\hline 2012 & 0.001 & 0.001 & 0.639 \\
\hline 2013 & 0.001 & 0.001 & 0.413 \\
\hline 2014 & 0.001 & 0.001 & 0.346 \\
\hline 2015 & 0.001 & 0.001 & 0.307 \\
\hline 2016 & 0.001 & 0.001 & 0.310 \\
\hline 2017 & 0.001 & 0.002 & 0.306 \\
\hline 2018 & 0.003 & 0.002 & 0.511 \\
\hline Average & 0.001 & 0.001 & 0.498 \\
\hline
\end{tabular}

Note: own calculation, 2019

Some of the problems that occur are the lack of support for the construction of transportation facilities and infrastructure in the development of the economic sector in Malinau Regency. The development is very necessary to support the pace of development of an area. The success in building efficient and safe transportation facilities and infrastructure has become the basis for economic development.

RCA index calculation is based on export volume data and export value of commodities in the Malinau Regency and the same export commodity at the North Kalimantan Province level from the agriculture sector. It is known that the three commodities above (palm oil, rubber, and wooden logs) both have less value than provisions, which means that all commodities have no comparative advantage. This is due to the contribution of the export value of the commodities of oil palm, rubber, and wooden logs of the Malinau Regency for 10 years, which is very minimal in the area of North Kalimantan Province.

Even though, when compared between the three commodities. The RCA value of wooden logs is higher until the mean reaches 0.496 , although the amount of exports increases every year. On the other hand, both oil palm and rubber commodities have a similar RCA index of 0.001 , where both the volume and value of exports also 
increased significantly but were not comparable to the level of North Kalimantan Province (see Table 6).

Table 7 shows that coal export products and minerals (types $\mathrm{A}, \mathrm{B}$, and $\mathrm{C}$ ) are proven to have a comparative advantage that is higher than the comparative advantage of commodity exports at the North Kalimantan Province level. while natural gas commodities do not. Coal and quarrying commodities (A, B, and C) have export product competitiveness, where for 10 years, the RCA value of the product is more than 1 or positive. but although the amount of RCA had decreased.

When compared to the export results of excavated commodities are higher than coal, where the average of these commodities even reached 2.369 and followed by new coal which only stood at 1.478 . Share natural gas commodities. RCA values below or less than 1 (0.391). where this shows the competitiveness of Malinau Regency natural gas export products using the RCA method from 2009-2018 is very weak to the level of the Province of North Kalimantan.

Table 7: Level of Competitiveness of Exports of Mining and Quarrying Sector Commodity Products in Malinau Regency, 2009-2018

\begin{tabular}{|c|c|c|c|}
\hline \multirow{2}{*}{ Year } & \multicolumn{3}{|c|}{ Commodity } \\
\cline { 2 - 4 } & Natural gas & Coal & $\begin{array}{c}\text { Excavation } \\
\text { (A, B, C) }\end{array}$ \\
\hline 2009 & 0.227 & 1.499 & 2.386 \\
\hline 2010 & 0.254 & 1.425 & 2.222 \\
\hline 2011 & 0.351 & 1.310 & 3.230 \\
\hline 2012 & 0.400 & 1.405 & 2.541 \\
\hline 2013 & 0.312 & 1.750 & 2.279 \\
\hline 2014 & 0.476 & 1.503 & 2.126 \\
\hline 2015 & 0.445 & 1.471 & 1.851 \\
\hline 2016 & 0.395 & 1.559 & 1.984 \\
\hline 2017 & 0.654 & 1.375 & 2.705 \\
\hline 2018 & 0.391 & 1.478 & 2.369 \\
\hline Avera & 0.391 & 1.478 & 2.369 \\
\hline ge & & &
\end{tabular}

Note: own calculation, 2019

The success in increasing exports also reflects an increase in competitiveness and, at the same time, is an indication of the growth of positive dynamics in a country's entrepreneurship. From this, increasing exports is no longer just a choice but a necessity.

The expansion of a country's international trade is also seen from its competitiveness, and this competitiveness is a general concept used in the economy, which refers to the commitment to market competition for its success in international competition. Competitiveness has become the key for companies, countries, and regions to succeed in their participation in globalization and free trade in the world (Blomqvist, 1976).

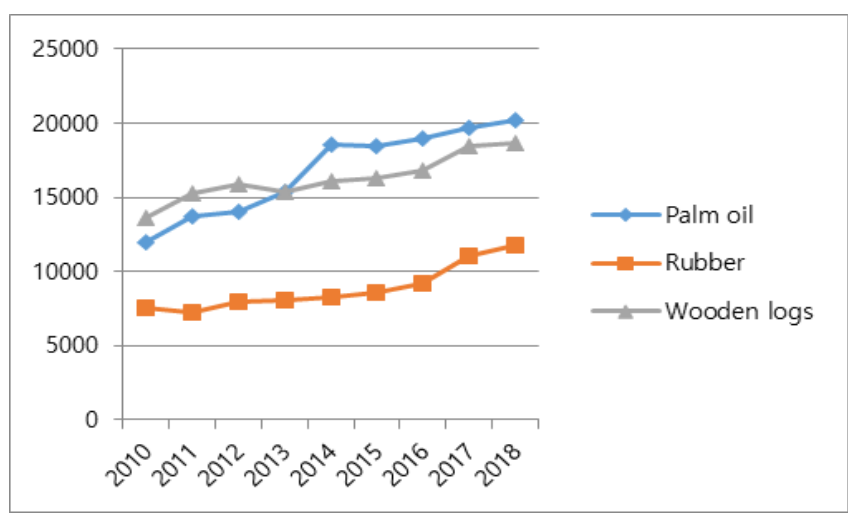

Figure 4: Volume of Commodity Exports of the Agriculture Sector in Malinau Regency, 2009-2018 (Tons)

Malinau is one of the regencies in the Province of North Kalimantan (separated from the Province of East Kalimantan) where the economic and livelihood activities of the majority of the population still depend on the agricultural sector and the mining and quarrying sector extensively. This capital-intensive sector is broadly one of the main pillars that give the biggest contribution in determining the progress and success of Malinau

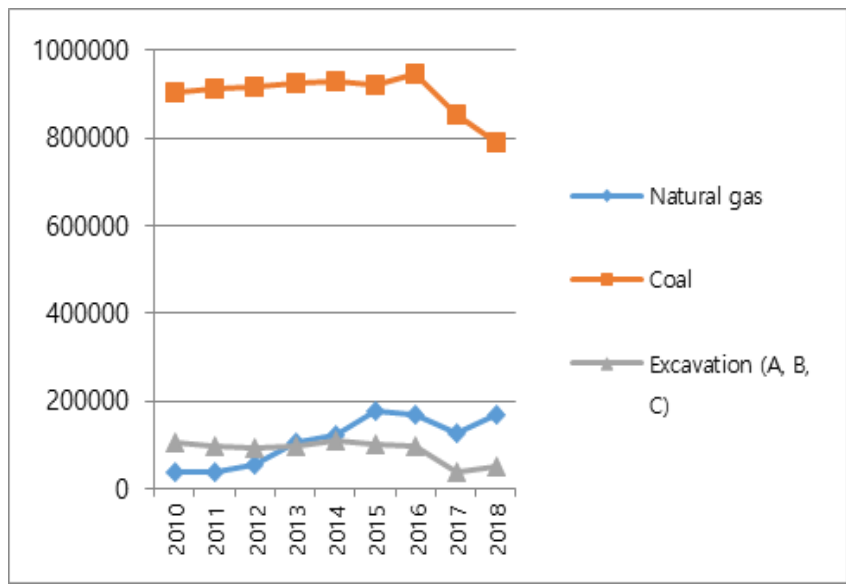

Figure 5: Volume of Commodity Exports of the Mining and Quarrying Sector in Malinau Regency, 2009-2018 (Tons)

Figure 4 shows if the export volume of 3 main commodities from the agricultural sector in Malinau Regency based on their quantity over the past 10 years has experienced a positive increase. Data shows that oil palm is the commodity with the largest volume as compared to the 
others, where the highest occurred was in 2018 of 20,173 tons. Wooden $\operatorname{logs}$ as the second largest commodity in which 2018 as the peak period with a magnitude of 18,639 tons and achievements of rubber commodities are ranked last with the same year of 11,721 tons.

When compared to the volume of commodity exports in the mining and quarrying sector in 2009-2018, Malinau Regency is more likely to rely on coal products than other commodities. Although of all the commodities this sector tends to fluctuate, the volume of coal exports is greater wherein 2015 reached 946,281 tons. Meanwhile, natural gas was ranked next with the highest exports of 176,090 tons in 2014, and mining or quarrying commodities (A, B, and C) ranked third where the highest achievement in 2013 was 110,386 tons (see Figure 5).

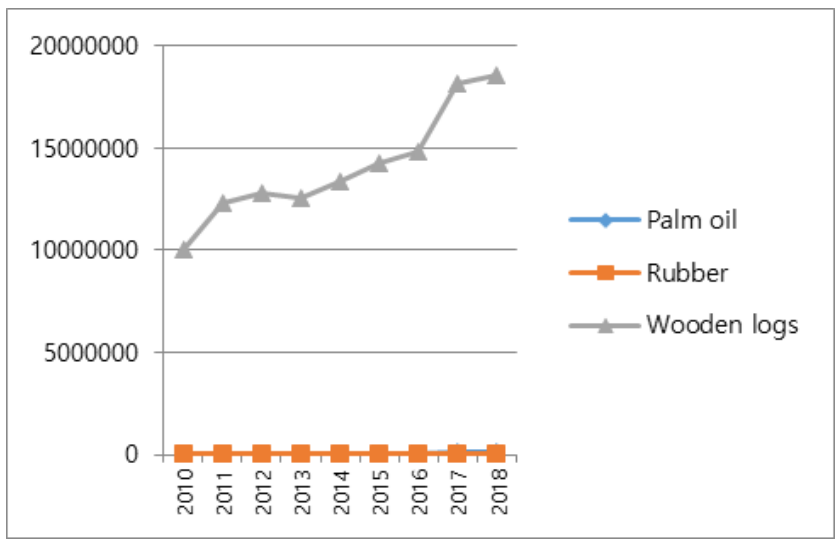

Figure 6: Value of Agricultural Sector Commodity Exportsin Malinau Regency, 2009-2018 (US\$)

The export results of 3 main commodities from the agricultural sector in Malinau Regency based on their value over the past 10 years have experienced a positive increase. Unlike the case in terms of volume quantity, the data shows that $\operatorname{logs}$ are the commodity with the largest export value as compared to the others, where the highest occurred in 2018 is U.S. $\$ 18,540,188$. Meanwhile, palm oil is the second largest commodity where, in the same year, it reached U.S. $\$ 83,642$, and the achievement of rubber commodity was in the last place at U.S. $\$ 37,300$ (Figure 6).

Figure 7, shows the value of commodity exports in the mining and quarrying sector during the observation object-. Malinau Regency is more likely to rely on coal products than other commodities. Although of all the commodities this sector tends to fluctuate, but the volume of coal exports is greater where most for 2015 reached U.S. $\$ 807,177,693$. Meanwhile, natural gas was ranked next with the highest exports of U.S. $\$ 132,950,883$ in 2014 , and commodity mining or quarrying (A, B C) occupies the third position where the highest achievement in 2013 was U.S. \$96,366,978.

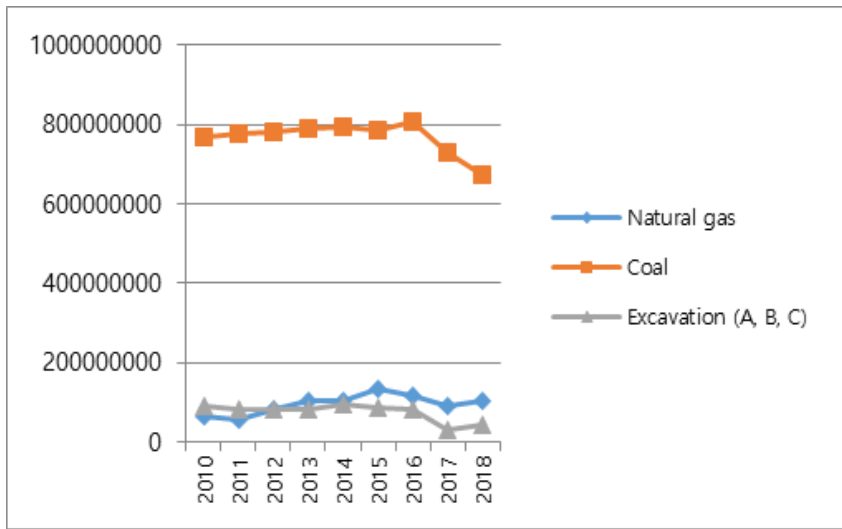

Figure 7: Value of Mining and Quarrying Sector Commodity Exports in Malinau Regency, 2009-2018 (US\$)

In international competition, especially in the competitiveness of export products, three aspects need to be considered are as follows:

- Price: In offering a product, the price must be the same or lower than the price offered by competitors, or the production cost is lower than the cost of production in the destination country. In this case, the exporting country has a comparative advantage.

- Product quality: The quality offered must meet or be in accordance with consumer tastes.

- Time of delivery: This must be under the situation and market conditions in the destination country. Delay in shipping and delivery of goods, can be fatal because it allows the product is no longer marketed so that it can reduce the appetite and demand for the product (Amir, 2003).

\section{Conclusions}

Leading sector results based on LQ Analysis in Malinau Regency are known to have six sectors, i.e: agriculture, electricity, gas and drinking water, building and construction, trading, hotel and restaurant, and services.

The result of a shift in the structure of the economy based on the classified SSA has been a change in the economic structure in Malinau Regency from the secondary to the tertiary and primary sectors in 10 years where the mining and quarrying sector penetrated the most dominant percentage as compared to others reaching $56.62 \%$.

The results of the competitiveness of export commodities in the Malinau Regency are based on the RCA. It is known 
that the three commodities from the agricultural sector (oil palm, rubber, and wooden logs) do not have a comparative advantage. While the mining and quarrying sector shows that coal and quarrying or quarrying export products (types $\mathrm{A}, \mathrm{B}$, and $\mathrm{C}$ ) are proven to have a comparative advantage higher than the comparative advantage of the same commodity exports at the level of North Kalimantan Province.

Analysis of economic growth in the Malinau Regency after regional autonomy shows that there has been a shift in the economic structure of the economy which is dominated by the structure of the primary sector. Not yet optimal and its dependence on the structure of the primary economic sector are the reasons why Malinau Regency is a developing region. Therefore, natural resource factors need to be managed and maintained properly, and it is hoped that the development carried out is oriented towards sustainable development, namely, a development that meets the needs of the present generation and without ignoring the interests of future generations in meeting their needs.

There has never been a similar study or previous research with the same time series, object, and analytical tool as this research. The scope is very focused on 1 region, so academics, government, and investors can adopt policies.

\section{References}

Amir, M. S. (2003). Ekspor Impor, Teori dan Penerapannya, Seri Bisnis Internasional (No. 13). Jakarta, Indonesia: Pustaka Binaman Pressindo (PPM).

Arsyad, L. (2010). Ekonomi Pembangunan, Edisi 5. Yogyakarta, Indonesia: UPP STIM YKPN.

Aswandi, H. M., \& Kuncoro, M. (2002). Evaluasi Penetapan Kawasan Andalan: Studi Empiris di Kalimantan Selatan 19931999. Jurnal Ekonomi dan Bisnis Indonesia, 17(1), 27-45. https://doi.org/10.22146/jieb.6703

Barro, R. J., \& Sala-i-Martin, X. (1992). Convergence. Journal of Political Economics, 100(2), 223-251. https://doi.org/10.1086/261816

Blomqvist, A. (1976). Patterns of development, 1950-1970: Hollis Chenery and Moises Syrquin (with the assistance of Hazel Elkington). Journal of Development Economics, 3(3), 300-301.

Borts, G. H. (1960). The Equalization of Returns and Regional Economic Growth. The American Economic Review, 50(3), 319-347.

Borts, G. H., \& Stein, J. L. (1964). Economic Growth in a Free Market. New York, NY: Columbia University Press.

Borts, G. H., \& Stein, J. L. (1968). Regional Growth and Maturity in the United States: A Study of Regional Structural Change. Swiss Journal of Economics and Statistics, 98(3), 290-321.

BPS-Statistics of Malinau Regency. (2019). Malinau Regency in Figures. Yogyakarta, Indonesia: Global Byakta Way Laay.

Chenery, H. B., \& Syrquin, M. (1975). Patterns of development 1950-1970. Oxford, England: Oxford University Press.

Chulanova, Z. K. (2017). The Human Capital as a Factor of
Competitiveness and Economic Development. Journal of Business Economics and Environmental Studies, 7(3), 23-31. https://doi.org/10.13106/eajbm.2017.vol7.no3.23

Darma, D. C. (2019). Determinants of the Gross Regional Domestic Product of East Kalimantan Province: Macroeconomic Variable Review. Review of Integrative Business and Economics Research, 9(1), 232-241.

Darma, D. C., Haryadi, H., \& Umiyati, E. (2015). Potensi Sektor Perekonomian di Kabupaten Malinau Provinsi Kalimantan Utara. Jurnal Perspektif Pembiayaan dan Pembangunan Daerah, 2(4), 173-180. https://doi.org/10.22437/ppd.v2i4.2613

Darma, D. C., Kasuma, J., \& Ikbal, M. (2020). Employment Absorption: Elasticity in the Industry and Services Sector in Indonesia. Management and Economics Review, 5(1), 125-135. https://doi.org/10.24818/mer/2020.06-10

Douglass C. N. (1955). Location Theory and Regional Economic Growth. Journal of Political Economy, 63(3), 243-258. https://doi.org/10.1086/257668

Kemal, A. R., Din, M. U., Qadir, U., Fernando, L., \& Colombage, S. (2002). Exports and Economic Growth in South Asia. A Study prepared for the South Asia Network of Economic Research Institutes. Islamabad, Pakistan: Pakistan Institute of Development Economics. Retrieved from http://saneinetwork.net/Files/02_05.pdf.

Kuncoro, M. (2003). Metode Riset untuk Bisnis \& Ekonomi. Jakarta, Indonesia: Erlangga.

Marshall, A. (1920). Principles of Economics: An Introductory Volume. London, England: MacMillan.

Marzuki, C. (1999). Metodologi Riset. Jakarta, Indonesia: Erlangga.

Miller, N. G., \& Geltner, D. M. (2004). Reviewed Work: Real Estate Principles for the New Economy. Journal of Real Estate Literature, 12(3), 407-409.

Nur, M. (2010). Statistika Deskriptif dan Induktif. Jakarta, Indonesia: Graha Ilmu.

Solow, R. M. (1956). Contribution to the Theory of Economic Growth. Quarterly Journal of Economics, 70(1), 65-94. https://doi.org/10.2307/1884513

Tarigan, R. (2005). The Relationship Between Alignment of Strategic Priorities (Between Functional Level and Business Level) and the Impact on Manufacturing Performance (Data From Indonesia). Jurnal Sistem Teknik Industri, 6(4), 8-15.

Tarigan, R. (2007). Teori dan Aplikasi Ekonomi Regional, Cetakan Keempat. Jakarta, Indonesia: Bumi Aksara.

Tiebout, C. M. (1956). Exports and Regional Economic Growth: A Reply. Journal of Political Economy, 64(2), 165-168. https://doi.org/10.1086/257771

Wahyuningsih, D., Yunaningsih, A., Priadana, M. S., Wijaya, A., Darma, D. C., \& Amalia, S. (2020a). The Dynamics of Economic Growth and Development Inequality in Borneo Island, Indonesia. Journal of Applied Economic Sciences, 67, 135-143. https://doi.org/10.14505/jaes.v15.1(67).12

Wahyuningsih, D., Yunaningsih, A., Priadana, M. S., Darma, D. C., \& Purwadi, P. (2020b). Why are Unemployment and Poverty Still Happening in Borneo Island, Indonesia? International Journal of Economics and Financial Issues, 10(2), 235-241. https://doi.org/10.32479/ijefi.9214 
Weiss, J. (2005). Export growth and industrial policy: Lessons from the East Asian miracle experience (ADB Institute Discussion Papers No. 26). Retrieved from http://siteresources.worldbank.org/EXTEXPCOMNET/Resour ces/2463593-1213975515123/17_Weiss.pdf
Wijayanti, T. C., \& Darma, D. C. (2019). The Role of Investment And Government Expenditure On Grdp And Human Development In East Kalimantan. International Journal of Scientific \& Technology Research, 8(9), 1232-1237. 